\title{
An entomological surveillance system based on open spatial information for participative dengue control
}

\author{
LEDA REGIS ${ }^{1}$, WAYNER V. SOUZA ${ }^{2}$, ANDRÉ F. FURTADO ${ }^{1}$, CLAUDIO D. FONSECA ${ }^{3}$, \\ JOSÉ C. SILVEIRA Jr. ${ }^{2}$, PAULO J. RIBEIRO Jr. ${ }^{4}$, MARIA ALICE V. MELO-SANTOS ${ }^{1}$, \\ MARILIA S. CARVALHO ${ }^{5}$ and ANTONIO M.V. MONTEIRO ${ }^{6}$ \\ ${ }^{1}$ Departamento de Entomologia, Centro de Pesquisas Aggeu Magalhães, Fundação Oswaldo Cruz \\ Caixa Postal 7472, Cidade Universitária, 50670-420 Recife, PE, Brasil \\ ${ }^{2}$ Departamento de Saúde Coletiva, Centro de Pesquisas Aggeu Magalhães, Fundação Oswaldo Cruz \\ Av. Prof. Moraes Rego s/n, 50670-420 Recife, PE, Brasil \\ ${ }^{3}$ Secretaria Estadual de Saúde de Pernambuco, Praça Oswaldo Cruz s/n, Boa Vista, 50050-210 Recife, PE, Brasil \\ ${ }^{4}$ Laboratório de Estatística e Geoinformação, Universidade Federal do Paraná (UFPR), \\ Caixa Postal 19081, 81531-990 Curitiba, PR, Brasil \\ ${ }^{5}$ Escola Nacional de Saúde Pública (ENSP), Fundação Oswaldo Cruz, Rua Leopoldo Bulhões, 1480 \\ Manguinhos, 21041-210 Rio de Janeiro, RJ, Brasil \\ ${ }^{6}$ Divisão de Processamento de Imagens e Programa Espaço e Sociedade, Instituto Nacional de Pesquisas Espaciais (INPE), \\ Av. dos Astronautas, 1758, Jd. Granja, 12227-010 São José dos Campos, SP, Brasil \\ Manuscript received on August 4, 2008; accepted for publication on March 2, 2009; \\ presented by JERSON L. SILVA
}

\begin{abstract}
Aedes aegypti is a very efficient disseminator of human pathogens. This condition is the result of evolutionary adaptations to frequent haematophagy, as well as to the colonization of countless types of habitats associated with environmental and cultural factors that favor the proliferation of this mosquito in urban ecosystems. Studies using sensitive methods of monitoring demonstrate that the methods of surveillance used in the Brazilian program do not show the high degrees of the infestation of cities by this vector. To increase the capacity of the health sector, new tools are needed to the practice of surveillance, which incorporate aspects of the vector, place and human population. We describe here the SMCP-Aedes - Monitoring System and Population Control of Aedes aegypti, aiming to provide an entomological surveillance framework as a basis for epidemiological surveillance of dengue. The SMCP-Aedes is uphold in the space technology information, supported by the intensive use of the web and free software to collect, store, analyze and disseminate information on the spatial-temporal distribution of the estimated density for the population of Aedes, based on data systematically collected with the use of ovitraps. Planned control interventions, intensified where and when indicated by the entomological surveillance, are agreed with the communities, relying on the permanent social mobilization.
\end{abstract}

Key words: dengue vector, entomological surveillance, ovitraps, GIS, vector control.

\section{INTRODUCTION}

According to the World Health Organization, over $40 \%$ of the world's population is at risk of acquiring dengue and there may be 50 million of new dengue infections

Correspondence to: Lêda Regis

E-mail: leda@cpqam.fiocruz.br every year. Innate characteristics of the dengue virus (DENV), which exists in four serotypes and can cause up to four infections per person, and of its main vector, Aedes aegypti, considered an extremely efficient disseminator of human pathogens, accounting for the expansion of the geographic distribution and, consequently, 
for the dramatic growth of the global burden of dengue in the last decades. Ae. aegypti is a highly anthropophilic species that feeds almost exclusively on humans (Scott et al. 1993, 2000, Harrington et al. 2001, Ponllawat and Harrington 2005). According to Harrington et al. (2001), the unique isoleucine concentration on human blood is associated with Ae. aegypti's unusual propensity to feed preferentially and frequently on humans - a behavior that increases this mosquito's fitness and, thus, is an underlying reason for its intimate contact with human hosts. The authors highlight that "from a public health perspective, selection for frequent human contact and an age-dependent increase in feeding frequency magnify the potential for transmission of pathogens by older potentially infected mosquitoes". Upon studying the blood meal frequency of Ae. aegypti field populations in Thailand, Scott et al. (2000) estimated that a female takes on average 0.76 human blood meal per day. These biological features of the vector have high epidemiological significance, and explain why Ae. aegypti's territory is the human house, from which it seldom leaves.

Evolution-driven adaptations to unstable habitats are also important factors to understand the role of this species as an efficient vector of pathogens: Ae. aegypti is an opportunistic container breeder. This mosquito is able to colonize all types of water holding containers; presents a fantastic resistance of its eggs chorion and the "skip oviposition behavior" of females (i.e. the spread of eggs from the same batch on different containers); and its larvae and pupae have the ability to dive deeper and for longer periods than other mosquito species (Koenraadt and Harrington 2008). It is crucial to consider these biological aspects and the consequences of their combination with environmental and climatic factors, as well as with anthropogenic habits that favor the mosquito proliferation, in order to understand the expansion and intensification of dengue and, most important, to choose adequate strategies and methods to monitor and control Ae. aegypti populations.

A protective tetravalent vaccine must be available if dengue is to be controlled. There are promising vaccine candidates under development (Trindade et al. 2008) and there is a possibility that this will be achieved in a few years (Whitehead et al. 2007, Edelman 2007). However, the well established Ae. aegypti populations in urban environments will remain as a matter of concern since other arboviruses may be transmitted by this species, such as Chikungunya and West Nile viruses.

The presence of this mosquito species was detected in $60 \%$ to $90 \%$ of the houses in Brazilian cities where sensitive surveillance methods were utilized to monitor Ae. aegypti populations, such as Salvador (Morato et al. 2005), Manaus (Ríos-Velasquez et al. 2007) and Recife (Regis et al. 2008). At the same time, the House Index (HI), used by the Brazilian National Program for Dengue Control, showed for these places negative or low values, seldom more than $10 \%$. The lack of sensitivity of entomological indices based on the visualization of immature stages, like the $\mathrm{HI}$ and the Breteau Index, is attributed to: a) the strong sensitivity and responsiveness of aedine pre-imaginal forms to water surface vibrations (Shuey et al. 1987), and their ability to make deep and long-duration dive and to perform bottom-resting (Romoser and Lucas 1999), thus making their visualization difficult; b) the information generated is the percentage of house/containers where the presence of one (or more) larva/pupa is observed during a visit that lasts a few minutes and takes place at every two months.

Despite its lack of sensitivity for detecting the presence of Aedes, and the fact that it does not quantify population size or density, this method proposed eight decades ago (Connor and Monroe 1923) is the only entomological surveillance tool used in most programs.

The complexities of the new urban realities point out new targets to the control of mosquito born diseases, such as dengue fever. To increase the capacity of the health sector for controlling transmissible diseases, new tools for epidemiological practice and surveillance must be developed. The SMCP-Aedes - System for Monitoring and Control of the Population of Aedes aegypti - is a contribution in this direction.

Dengue vector surveillance is important to determine when and where to apply the control actions. An entomological surveillance system able to generate quantitative information on mosquito population densities and helping to predict explosive population growth is essential for launching actions to prevent epidemics to occur. The importance of the entomologic surveillance 
as a base for dengue transmission control has been recently highlighted by Ooi et al. (2006).

\section{THE SMCP-Aedes, A SPATIAL SURVEILLANCE SYSTEM}

The main underlying concept within the SMCP-Aedes is to integrate biological aspects of the vector with human population and environmental data through building an entomological surveillance system based on geographical information, as a support for dengue epidemiological surveillance and control at intra-urban scales. To do so, the SMCP-Aedes makes intensive use of open spatial technology solutions. It is based on open protocols and open standards, an intensive use of web and open software for GIS and Database Management workingup information stored in a spatial-temporal database from where they can be explored through quantitative methods. The Aedes population in a certain urban area can be estimated and its spatial-temporal distribution visualized, based on continuous eggs collection. Control interventions can be planned and intensified on the basis of spatial analysis carried on by the SCMP-Aedes. These actions to be taken by the local health services can be agreed with the local community. In this sense, the SMCP-Aedes can be instrumental for helping the building-up of a permanent social mobilization towards a more effective vector control.

The sample design was conducted supposing to overlap a grid with 400 cells with $50 \mathrm{~m} \times 50 \mathrm{~m}$ each one, for a territory of $1 \mathrm{~km}^{2}$. Depending on the household density in the area, the sample size (number of cells) was calculated by fitting a logistic function (Fig. 1), taking into account the following parameters: 10 cells for very low densities (i.e. 100 or less households per $\mathrm{km}^{2}$ ); 100 cells for intermediate density (i.e. almost 3.000 households per $\mathrm{km}^{2}$ ) as adopted in a previous experiment (Regis et al. 2008); and an upper boundary of 200 (50\% of the total) cells for very high densities.

$$
Y=\frac{1}{\frac{1}{u}+b_{0} \times b_{1}^{X}}
$$

where $Y$ is the number of cells to be sampled which will receive one ovitrap; $u$ is the upper boundary; $X$ is the mean number of households per $\mathrm{km}^{2}$; and $b_{0}$ and $b_{1}$ are the parameters estimated by the model.
Each trap was allocated inside the cell space and the coordinates of the location was taken using a Global Positioning System (GPS) and recorded at an integrated geographic information system.

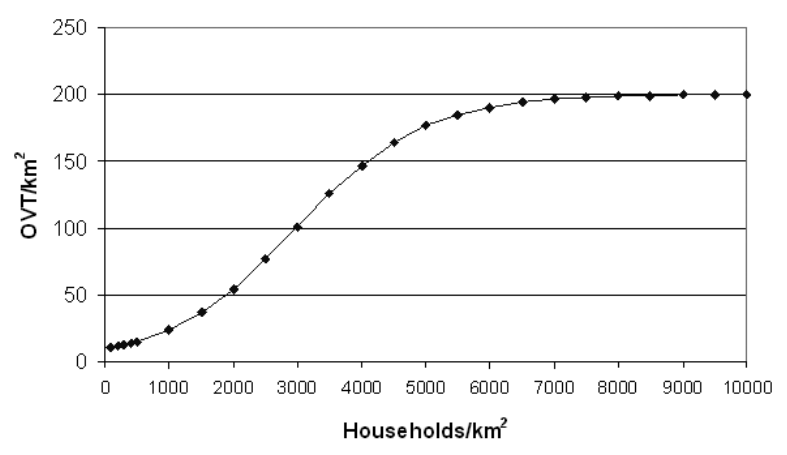

Fig. 1 - Logistic function describing the number of cells to be sampled according to the household density.

A sensitive, safe, low cost and easy to use tool is suitable for continuous egg-collection at a number of fixed sampling stations in order to monitor reproductively active populations. This can be accomplished with an ovitrap model consisting of a black plastic cup baited with $2 \mathrm{~L}$ of grass infusion (or water supplemented with alfalfa pellets) treated with a Bti-based product and containing three $5 \times 15 \mathrm{~cm}$ wooden paddles, as oviposition substrates (Regis et al. 2008). Besides being a potent, safe and long lasting larvicide specially under shade (Regis et al. 2001, Araújo et al. 2007, MeloSantos et al. 2009), Bti seems to act as an oviposition stimulant (Santos et al. 2003, Stoops 2005), giving increased efficiency to the trap, which can safely remain in the field for up to two months showing an egg-collection capacity of over 7.000 eggs/trap-month (Regis et al. 2008). An egg counting computer-assisted system (Mello et al. 2008) allows operational advantages over the optical microscopic counting system. It is less time-consuming and data records are directly transferred to a geographical database.

\section{THE SMCP-Aedes CONCEPTUAL ARCHITECTURE AND OPEN TECHNOLOGIES}

The decision on supporting technology for the SMCPAedes is based around open software and open standards for geospatial data. It goes in line with our previous work in Recife (Regis et al. 2008) and with the re- 
cent works linked with health information systems that have taken the same lines (Qian Yi et al. 2008, MorenoSanches et al. 2007). The database logic model has been based upon the Recife-SAUDAVEL-GED. For the first version of the SMCP-Aedes, we have taken the open MySQL Database Server as the repository for the geographic entomological database. The MySQL DBMS software is embedded by the open TerraLib GIS library (www.dpi.inpe.br/terralib) allowing for the spatial-temporal models to store, retrieve and analyze the data. The eggs counts are recorded on the database by using a web-based interface that has been developed by the SAUDAVEL network (Monteiro et al. 2005) at the National Institute for Spatial Research - INPE and at $\mathrm{CPqAM} /$ Fiocruz and adapted for this system. The database contains other data as demographic data at the census tract scale, satellite images of the region and all mapping information available for the sites where the ovitraps have been installed. We have adopted TerraView (www.dpi.inpe.br/terraview), an open GIS application that runs on desktop computers, as a browsing tool for this geographic database which provides quick summaries for some spatial-temporal queries in the stored data, and an integrated environment for visualization of data, remote sensing satellite imagery, pictures of the traps and census tract data.

Within the SMCP-Aedes system, assessments and decision making are based on reports that are produced systematically and automatically incorporating the latest available data. Typically, such outputs make use of statistical analysis and modeling tools beyond the GIS capabilities which are implemented by scripts (Bonat et al. 2008) which are written using the R statistical computing language (R DEVELOPMENT CORE TEAM 2009). Such scripts can be modular, implementing requested analysis and the associated reporting formats running automatically on the data base server. The $\mathrm{R}$ add-on package aRT (Andrade et al. 2005) provides a software binder for integrating TerraLib GIS library and R. Specific routines for statistical, and in particular spatial and/or temporal analysis, are implemented by another R package, RDengue, tailored to the specific needs of the project and designed to release automatic analysis of the data stored into the SMCP-Aedes geographical database (Dallazuanna et al. 2008). Figure 2 displays a schematic view of this architecture and detailed schemes; and some example outputs can be seen in Figure 3.

\section{INTEGRATED VECTOR CONTROL BASED ON ENTOMOLOGICAL SURVEILLANCE}

The National Program of dengue control, PNCD, established in Brazil in 2002, is implemented by the Ministry of Health in partnership with the 27 states and 5,560 municipalities. The PNCD foresee the implementation of vector control activities, among other components. The vector control is based essentially on the work of health workers carrying out registration of houses and the use of temephos as larvicide. In the last 12 years, large amounts of organophosphates have been routinely applied in cycles of two months with high operational cost. Other insecticides (organophosphates and pyrethroids) are used as adulticides. The application of larvicides and adulticides will hardly reach the control pressure to reduce populations of this species in a satisfactory way due to known behavioral and biological characteristics, peculiar to Ae. aegypti, in addition to the fact that mosquito populations develop inevitably a resistance to these compounds, as has been detected in the country since 2000 .

The vector control measures proposed here are based on the temporal and spatial distribution of reproductively active mosquito populations, as estimated from eggs collected in the sentinel ovitraps. The aim is to prevent mosquito population outbreaks associated with the seasonal increase of dengue cases by intensifying control measures in specific places at specific times. In Recife, it was observed that the first rainfall after the dry season, associated with the season's high temperatures promoting a massive mosquito egg hatching, resulted in very high mosquito densities from January to August, which match the dengue season. As we have experimentally demonstrated in an urban neighborhood (Regis et al. 2008), such a vector population boost can be prevented through egg mass collection using 4,000 controlovitraps $/ \mathrm{km}^{2}$. At the same time, entomological spatial analysis in seven different urban sites in Recife allowed the identification of intra-site areas where mosquito populations were persistently most concentrated (Regis et al. 2008). 


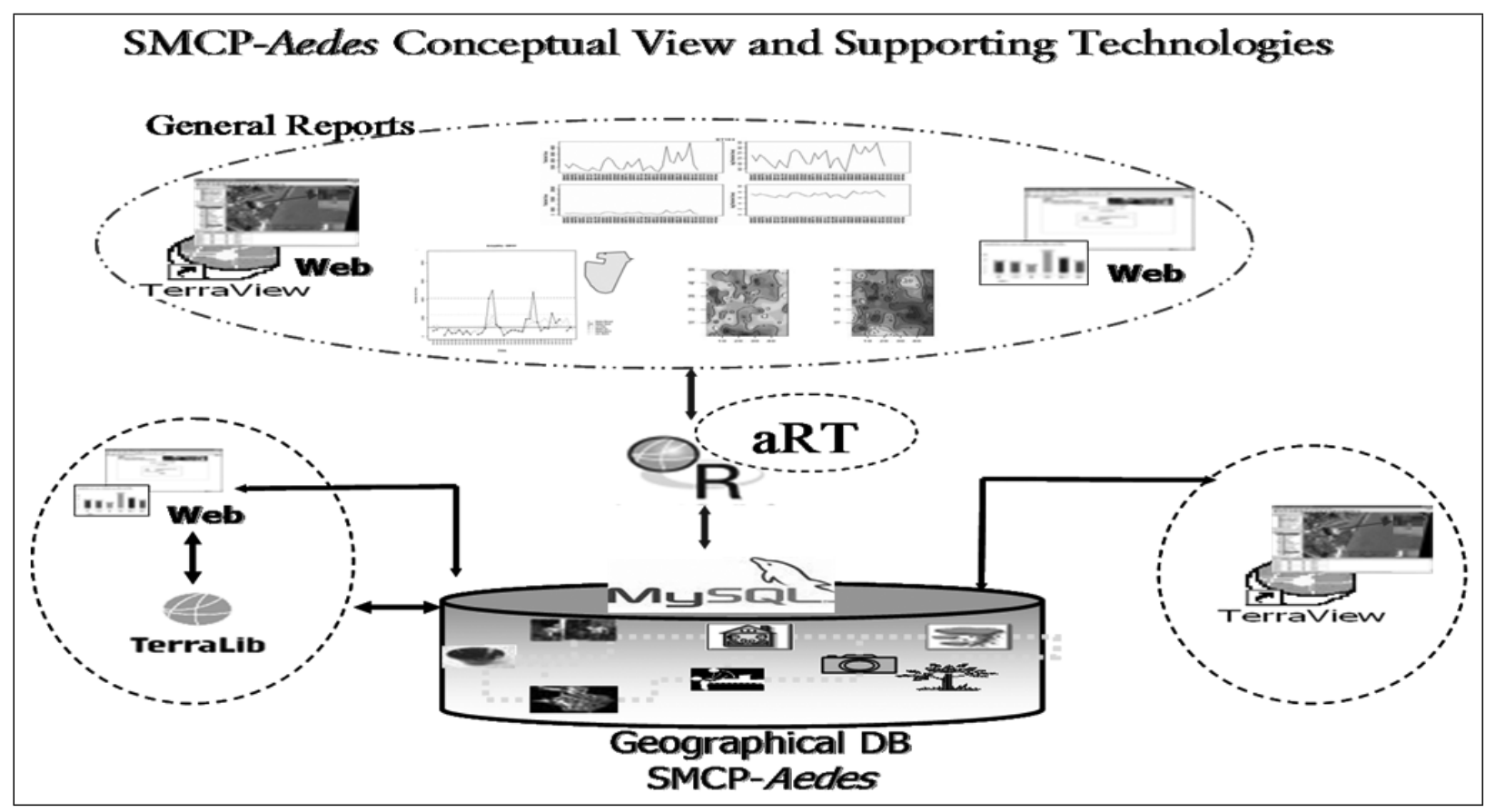

Fig. 2-A General Conceptual Scheme for the Computational Architecture of the SMCP-Aedes including the open set of spatial technologies chosen for implementation of the system. It involves open GIS library TerraLib, the open GIS application TerraView, the open database management system MySQL and the aRT - an Application Programming Interface for binding R to TerraLib running the RDengue statistical analysis package.

The strategy proposed in the SMCP-Aedes is to combine larval source reduction by eliminating, properly covering or applying Bti as a larvicide in potential larval habitats, with mass collection/destruction of eggs, through an agreement between public health services and the local community. In this strategy, the use of ovitraps is essential to avoid gravid females to disperse in the search for oviposition sites. The public must be aware that the lower the amount of available breeding sites in a house, the higher the amount of eggs that will be laid in an ovitrap. Another important aspect is that the oviposition substrate used in these ovitraps (cotton fabric, according to Lenhart et al. 2005) allows the visualization of Aedes eggs by the householders, and it is easier to be incinerated (for egg destruction) than wooden substrates. For security reasons, the Government should take responsibility for egg incineration and supply of larvicides based on Bti to be used in the ovitraps.

Besides these actions, aiming to avoid a general mosquito population growth, the strategy also includes control interventions targeting the hotspots and focusing on mechanical elimination of adult mosquitoes from houses located in these areas. The use of aspirators for indoor collection of adult mosquitoes has several advantages over the use of organophosphorous or pyretroids as adulticides: it does not offer any health risk for humans and domestic animals; the method is efficient and effective since mosquitoes are caught directly from their resting places within the house; householders are able to see the mosquito capture; and results are measurable. It is expected that the vector population is impacted by indoors mosquito captures repeated fortnightly for two consecutive months within houses containing two or three ovitraps for egg collection-destruction and where potential breeding sites are properly managed. These control strategies are currently under evaluation in a large-scale pilot experiment in two cities of Pernambuco, Brazil.

\section{FINAL REMARKS}

Built on an interdisciplinary approach, the SMCPAedes was developed and assessed based on a longitudinal study conducted at Recife-PE over a 4 years period (Regis et al. 2008). It has now been putting into action as a pilot program in two cities of the Pernam- 


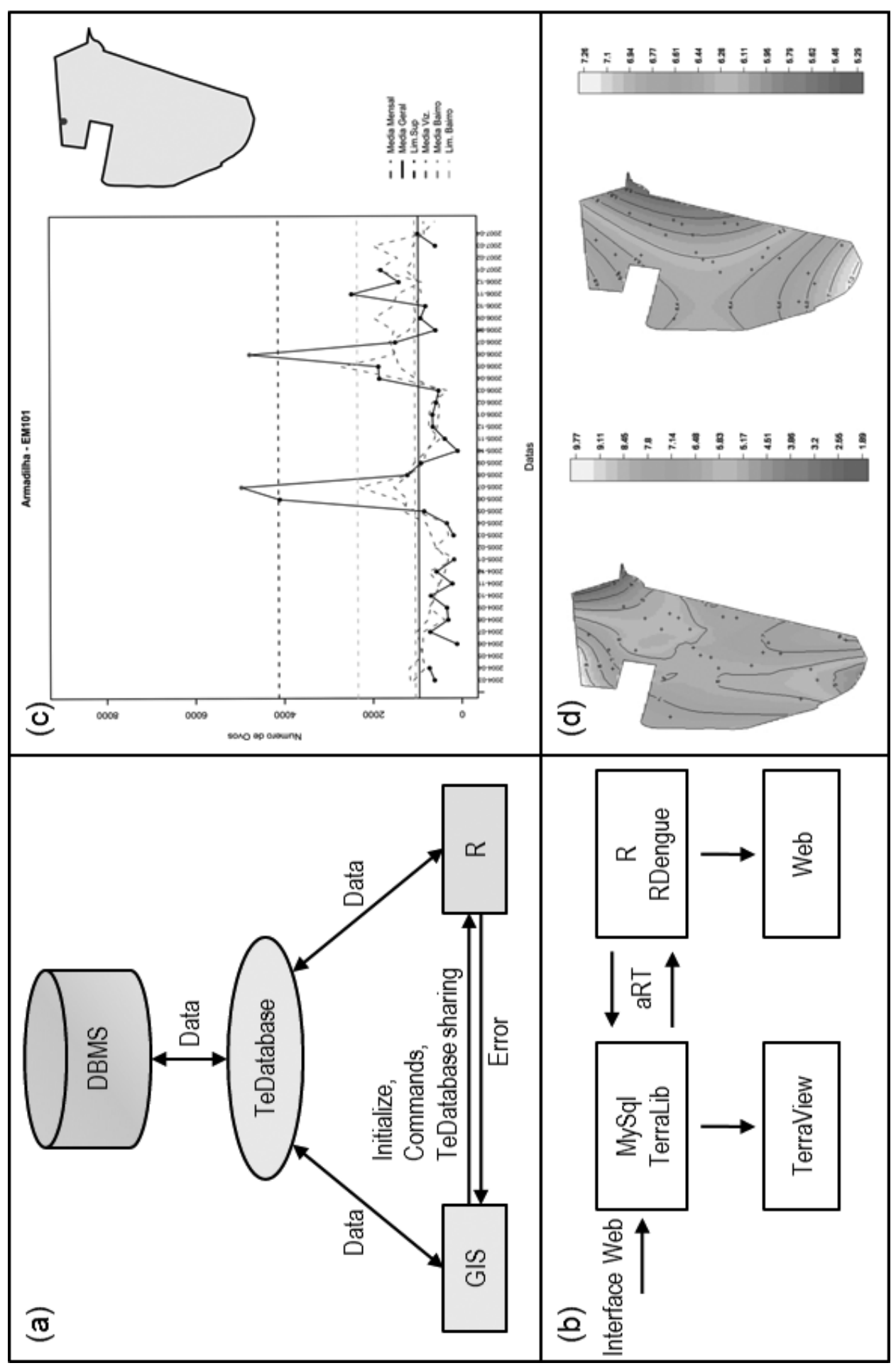

Fig. 3 - (a) A simplified scheme showing the interaction amongst an open DBMS system, the open TerraLib GIS library and the open statistical computing environment R; (b) A schematic view on how the open technologies work together to promote spatial analysis and visualization of the entomological and geographical data; (c) An example of analysis carried out by the RDengue to a specific ovitrap showing its placement and statistical summaries relating the average egg counting on that trap against its neighbors over time; (d) Another example of RDengue possibilities showing a hotspot map for a specific site that displays the estimated vector density based on the ovitraps counting over a certain period. 
buco state, Brazil, in a joint effort involving the state health authority, the local health services, research institutions (Fiocruz and INPE) and the SAUDAVEL network (Monteiro et al. 2005). The system is designed to generate automatic analysis and reports. Besides, it uses open software produced in Brazil namely the Ter$\mathrm{raLib} /$ TerraView, aRT and RDengue, combined with a $\mathrm{R}$ software for statistical computing and a database management system. The following-up of the outcomes of the program in the pilot cities of Santa Cruz do Capibaribe-PE and Ipojuca-PE is expected to demonstrate how open spatial information technology can contribute to establish an entomological surveillance strongly based on open spatial technology solutions with low cost and high efficiency.

\section{ACKNOWLEDGMENTS}

This work was supported by Conselho Nacional de Desenvolvimento Científico e Tecnológico (CNPq), Fundação Oswaldo Cruz - Programa de Desenvolvimento e Inovação Tecnológica em Saúde Pública (FiocruzPDTSP)/Rede Dengue, Ministério da Saúde/Departamento de Ciência e Tecnologia (MS-Decit)/UNESCO, and Fundação de Amparo à Ciência e Tecnologia de Pernambuco (FACEPE).

\section{RESUMO}

Associadas a fatores bióticos, climáticos e culturais que favorecem a proliferação do Aedes aegypti em ecossistemas urbanos, adaptações evolutivas à hematofagia freqüente e quase exclusiva em humanos e à colonização de tipos infinitos de habitats, fazem deste mosquito um disseminador extremamente eficiente de patógenos ao homem. Estudos utilizando métodos sensíveis de monitoramento demonstram que os métodos de vigilância usados no programa brasileiro não revelam as elevadas intensidades da infestação das cidades por este vetor. Para ampliar a capacidade do setor de saúde novos instrumentos são necessários à prática da vigilância, incorporando aspectos do vetor, do lugar e das pessoas do lugar. Apresentamos aqui o SMCP-Aedes - Sistema de Monitoramento e Controle Populacional do Ae. aegypti, cuja meta é a instrumentalização da vigilância entomológica como base para a vigilância epidemiológica da dengue. Para isso ele se apóia em tecnologias da informação espacial baseadas no uso intensivo da web e de software livre para coletar, armazenar, analisar e disse- minar informações relativas à distribuição espaço-temporal da densidade estimada para a população do Aedes, com base em amostras obtidas continuamente com ovitrampas. Intervenções de controle planejadas e intensificadas onde e quando indicado pela vigilância entomológica, são pactuadas com os habitantes, apoiando-se na mobilização social permanente.

Palavras-chave: vetor da dengue, vigilância entomológica, ovitrampas, SIG, controle do vetor.

\section{REFERENCES}

ANDRADE PR, RiBeIRo JR PJ AND FoOK KD. 2005. Integration of Statistics and Geographic Information Systems: the R/TerraLib Case. Proceedings of GeoInfo p. 139-151.

Araújo AP, Melo-Santos MAV, Carlos SO, Rios EMM AND REGIS L. 2007. Evaluation of an experimental product based on Bacillus thuringiensis sorovar. israelensis against Aedes aegypti larvae (Diptera: Culicidae). Biol Control 41: 339-347.

Bonat WR, Dallazuanna HS AND Ribeiro JR PJ. 2008. Investigando fatores associados a contagens de ovos de Aedes aegypti coletados em ovitrampas em Recife, PE. Relatório Técnico, Laboratório de Estatística e Geoinformação, UFPR

Connor ME And Monroe WM. 1923. Stegomyia indices and their value in yellow fever control. Am J Trop Med Hyg 3: 9-19.

Dallazuanna HS, Bonat WR AND Ribeiro JR PJ. 2008. RDengue: pacote de apoio à análise para monitoramento de ovos do Aedes aegypti. Versão 1.0. Available from: http://www.leg.ufpr.br/RDengue.

Edelman R. 2007. Dengue Vaccines Approach the Finish Line. Clin Infect Dis 45: S56-S60.

HARRINGTON LC, EDMAN JD AND SCOTT TW. 2001. Why do female Aedes aegypti (Diptera: Culicidae) feed preferentially and frequently on human blood? J Med Entomol 38: 411-422.

KoenraAdt CJ And Harrington LC. 2008. Flushing Effect of Rain on Container-Inhabiting Mosquitoes Aedes aegypti and Culex pipiens (Diptera: Culicidae) J Med Entomol 45: 28-35.

Lenhart AE, Walle M, Cedillo H and Kroeger A. 2005. Building a better ovitrap for detecting Aedes aegypti oviposition. Acta Trop 96: 56-59.

Mello CAB, Santos WP, Rodrigues MaB, Candeias ALB And Gusmão CMG. 2008. Image Segmentation of Ovitraps for Automatic Counting of Aedes aegypti 
Eggs. In: $30^{\mathrm{TH}}$ ANNUAL InTERnATIONAL CONFERENCE OF THE IEEE ENGINEERING IN MEDICINE AND Biology Society, August 20-24 2008, Vancouver, Canada. Paper FrDPo07.14. http://www.embc2008.com/.

Melo-Santos MAV, AraúJo AP, Rios EMM AND REGIS L. 2009. Long lasting persistence of Bacillus thuringiensis serovar. israelensis larvicidal activity in Aedes aegypti (Diptera: Culicidae) breeding places is associated to bacteria recycling. Biological Control 49: 186-191.

Monteiro AMV, Carvalho MS, Assunção R, Souza WV, Ribeiro Jr PJ, DAVis JR C, Regis L AND the SAUdAVEl Project TeAm. 2005. SAUDAVEL: Bridging the Gap between Research and Services in Public Health Operational Programs by Multi-Institutional Networking Development and Use of Spatial Information Technology Innovative Tools. [cited 2008 Jan 10]. Available from: http://www.dpi.inpe.br/saudavel/publicacoes.html.

Morato VCG, Teixeira MG, Gomes AC, BergamasCHI DP AND BARRETO M. 2005. Infestation of Aedes aegypti estimated by oviposition traps in Brazil. Rev Saúde Pub 39: 553-558.

Moreno-Sanchez R, Anderson G, Cruz J And HayDEN M. 2007. The potential for the use of Open Source Software and Open Specifications in creating Web-based cross-border health spatial information systems. Int $\mathrm{J}$ Geogr Inf Sci 21: 1135-1163.

Ooi E-E, Goh K-T And Gubler DJ. 2006 Dengue Prevention and 35 Years of Vector Control in Singapore. Emerg Infect 12: 887-893.

PONLlAWAT A AND HARRINGTON L. 2005. Blood feeding patterns of Aedes aegypti and Aedes albopictus in Thailand. J Med Entomol 42: 844-849.

QIAN YI ET AL. 2008. Integrating open-source technologies to build low-cost information systems for improved access to public health data. Int J Health Geogr 7: 29.

R Development Core Team. 2009. R: A language and environment for statistical computing. R Foundation for Statistical Computing, Vienna, Austria. ISBN 3-90005107-0, URL http://www.R-project.org.

Regis L, Silva-Filha MH, Nielsen-LeRoux C AND CHARLES JF. 2001. Bacteriological larvicides of dipteran disease vectors. Trends Parasitol 17: 377-380.
REGIS L ET AL. 2008. Developing new approaches for detecting and preventing Aedes aegypti population outbreaks: basis for surveillance, alert and control system. Mem Inst Oswaldo Cruz 103: 50-59.

Ríos-Velasquez CM, CODEÇO CT, Honório NA, Sabrosa PS, Moresco M, Cunha ICL, Levino A, Toledo LM AND Luz SLB. 2007. Distributions of dengue vectors in neibghborhoods with different urbanization types of Manaus, state of Amazonas, Brazil. Mem Inst Oswaldo Cruz 102: 617-623.

Romoser WS AND LuCAS EA. 1999. Buoyancy and diving behavior in mosquito pupae. J Am Mosq Contr Assoc 15: 194-199.

SAntos SRA, Melo-SAntos MAV, Regis L And AlBUQUERQUE CMR. 2003. Field evaluation of ovitraps consociated with grass infusion and Bacillus thuringiensis var. israelensis to determine oviposition rates. Dengue Bull 27: 156-162.

Scott TW, Chow E, Strickman D, Kittayapong P, WIRTZ RA AND EDMAN JD. 1993. Blood feeding patterns of Aedes aegypti collected in a rural Thai village. J Med Entomol 30: 922-927.

Scott TW, Amerasinghe PH, Morrison AC, LoRENZ LH, Clark GG, StrickMAN D, KitTAYAPONG P AND EDMAN JD. 2000. Longitudinal studies of Aedes aegypti (L.) (Diperta: Culicidae) in Thailand and Puerto Rico: Blood feeding frequency. J Med Entomol 37: 89-101.

SHUEy JA, BuCCI AJ AND Romoser WS. 1987. A behavioral mechanism for resting site selection by pupae in three mosquito species. J Am Mosq Control Assoc 3: 65-69.

Stoops CA. 2005. Influence of Bacillus thuringiensis var. israelensis on oviposition of Aedes albopictus (Skuse). J Vector Ecol 30: 41-44.

Trindade GF, Marchevsky RS, De Fillipis AMB, Nogueira RMR, Bonaldo MC, ACERo PC, CARIDE E, Freire MS AND GALler R. 2008. Limited replication of yellow fever 17DD and 17D-Dengue recombinant viruses in rhesus monkeys. An Acad Bras Cienc 80: 311-321.

Whitehead SS, Blaney JE, Durbin AP And Murphy BR. 2007. Prospects for a dengue virus vaccine. Nat Rev Microbiol 5: 518-528. 